\title{
The Use of Cambridge Scriptural Reasoning (CSR) Texts for Inter-Faith Dialogue in Classroom: Some Pedagogical Proposals
}

\author{
Denni Saragih*, Yanny Mokorowu, Prasasti Peranginangin
}

Krida Wacana Christian University, Centre of Holistic Education, Jl. Tanjung Duren, 4, Jakarta, 11470, Indonesia

\begin{abstract}
Recent developments in Indonesian society show an alarming growth of religious intolerance. The paper proposes that one of ways that can contribute to remedy the situation is an Inter-faith dialogue in classroom using Cambridge Scriptural Reasoning (CSR) texts. The texts provide a primary source for understanding fundamental beliefs and focus on less controversial issues. Acknowledging the sensitivity of handling religious texts, the paper reports an exploration of the possibility and challenges of doing interfaith dialogues in a classroom using CSR texts. Based on several class experiments and qualitative interviews of the participants, the approach results in positive experience of the participants. The paper, thus, recommends three pedagogical principles. The use of the texts must have the consent of all students; the conclusion of textual meaning gives a prominent authority to the insights of its adherent; and at the end of each session, students from other religions provide testimonial on changed perception through the dialogue. As such, the paper recommends the use of CSR texts in a course on religion, particularly in Christian universities in Indonesia, as a contribution to mutual understanding and religious harmony.
\end{abstract}

Keywords: Christian university, inter-faith, pedagogy, scripturalreasoning, tolerance.

\section{Introduction}

Komaruddin Hidayat [1], a prominent Muslim intellect in Indonesia, notes that fundamentalism has creeped into educational system in Indonesia, and one of the reasons for its success is a common superficial understanding of religious teaching. As such, it is not a surprise that according to a recent report by Wahid Foundation [2], there is an alarming percentage of people in Indonesia who supported radicalism $(7.7 \%)$ and a worrying percentage of those who involved in at least one form of intolerant activities $(0.4$ $\%)$. In its conclusion, the report recommends the importance of regular citizens to have an inclusive and humanist understanding of religion "based on the belief in the One Almighty God in order to achieve social justice for all in a united Indonesia." According to the same report, some characteristics of radicals groups in Indonesia are "tend to hold narrowly literal understanding of religious teachings" and "tend to have exposed to religious information containing messages of suspicion and hatred" [3]. The situation is a real challenge for mutual understanding and religious harmony in Indonesia.

One of the ways the problem can be address by improving mutual religious understanding among regular citizens i.e. by engaging each other in a healthy and peaceful inter-faith dialogue. On the other hand, inter-faith dialogue is not a norm among students in Indonesia [4]. For many, engaging each other in religious conversation is at most 
superficial and more commonly rife with mutual misunderstandings. Reading and discussing soberly Holy Scriptures of other faiths is a rare event, even if there is, inter-faith dialogue is commonly marked by low quality engagements and disagreements. The attitude of participants is commonly apologetics, combined with the feeling of suspicion and the style of combative response or critical interjection.

This paper explores the possibility and the pedagogical principles of doing high quality inter-faith dialogues in a university classroom. While the long-term objective is to design a tool that helps an inter-faith dialogue in a local community as part of service-learning project, the focus of this paper is limited to the experience of the students during inter-faith experiments. The research question pursued is to understand the experiences of those who participate in an inter-faith dialogue in a university class-setting. Specifically, the paper presents the result of a qualitative research on a pedagogical-experimentation in the class on Religion in the Krida Wacana Christian University (Universitas Kristen Krida Wacana Ukrida). The dialogues were conducted by using the Cambridge Scriptural Reasoning (CSR) texts, and the experiments show the positive impacts to students' experience and the increasing feeling of tolerance. Another important result is the pedagogical principles learnt in using the text for inter-faith dialogue that can be applied in other setting. The paper will consist of three parts: an introduction to CSR text, including the reasons and challenges using it, a report on qualitative interview of participating students, and some pedagogical principles for using the texts in Indonesia.

\section{The Cambridge scriptural reasoning text (CSR text)}

The CSR text is a tool created for inter-faith dialogue by Cambridge University's InterFaith Programme [5]. The purpose of the project is to help people from different religious background to read together their Scriptures across religious perspectives [6]. It has a distinctive approach in which, "Unlike some forms of inter-faith engagement, it is not about seeking agreement but rather exploring the texts and their possible interpretations across faith boundaries, and learning to disagree better" [7]. The approach aims at a deeper understanding of one's Holy Scripture in conversation with others, and also to inspire bonds and mutual understandings between different religious backgrounds. Its application in a school setting aims to "equips young people with skills in respectful dialogue and introduces them to the idea of better quality disagreement" [8]. These characteristics persuaded us in Ukrida to test the text in the class. The contexts are clearly different, but the basic approach that aims at 'better quality disagreement', is fascinating enough to explore what would happen in the context of a Christian university in Indonesia.

The CSR texts, at the moment, consists of nineteen textual sets collected from Jewish, Christian and Islam Holy Scriptures which teach similar themes [9]. The experiments were conducted in five class meetings using texts number 3 (Beginning), 6 (Clothing and Modesty), 9 (Created Human), 12 and 13 (Encountering God 1 and 2). The complete list of the text can be found in the Table 1 .

Table 1. List of textual set compiled in CSR

\begin{tabular}{|c|c|c|c|c|}
\hline Text & Theme & Hebrew Scripture & New Testament & Quran \\
\hline 1. & $\begin{array}{c}\text { Abraham's } \\
\text { Hospitality }\end{array}$ & Genesis 18:1-18 & Hebrew 13:1-2 & $\begin{array}{c}\text { Scattering [Wind] } \\
51: 24-30\end{array}$ \\
\hline 2. & $\begin{array}{c}\text { Abraham's } \\
\text { Journey }\end{array}$ & Genesis 12:1-9 & Hebrew 11:8-16 & $\begin{array}{c}\text { Chapter 14 } \\
\text { (Abraham):37 }\end{array}$ \\
\hline
\end{tabular}

Table1. continue to the next page 
Table1. List of textual set compiled in CSR (Continued)

\begin{tabular}{|c|c|c|c|c|}
\hline Text & Theme & Hebrew Scripture & New Testament & Quran \\
\hline 3. & Beginning 1 & Genesis $1: 1-5$ & John $1: 1-5$ & $\begin{array}{c}\text { [Verses] Made } \\
\text { Distinct 41:10-12 }\end{array}$ \\
\hline 4. & $\begin{array}{l}\text { Beginning 2: } \\
\text { Humanity }\end{array}$ & Genesis 1:26-29 & Genesis $2: 4-9$ & The Cow, 2:29-33 \\
\hline 5. & Cain and Abel & Genesis 4:1-16 & Matthew 23:29-39 & The Feast, 5:27-32 \\
\hline 6. & $\begin{array}{l}\text { Clothing and } \\
\text { Modesty }\end{array}$ & Genesis $24: 64-67$ & 1 Timothy $2: 8-10$ & Light, 24:30 \\
\hline 7. & Covenant & Genesis 9:8-17 & Luk 22:14-20 & $\begin{array}{l}\text { The Cow, } \\
\text { 2:124-129 }\end{array}$ \\
\hline 8. & $\begin{array}{c}\text { Craft and } \\
\text { Construction }\end{array}$ & Exodus 31:1-11 & $\begin{array}{c}1 \text { Corinthians } \\
3: 10-15 \\
\end{array}$ & Sheba $34: 10-13$ \\
\hline 9. & Created Human & Genesis 1:26-28 & $\begin{array}{l}1 \text { Corinthians } \\
15: 42-49\end{array}$ & $\begin{array}{c}\text { The Throngs, } \\
39: 6-7\end{array}$ \\
\hline 10. & $\begin{array}{c}\text { Delegating } \\
\text { Responsibility }\end{array}$ & Genesis $41: 38-45$ & Acts $6: 1-7$ & $\begin{array}{c}\text { Surah Taha } \\
20: 25-36\end{array}$ \\
\hline 11. & Dreams & Genesis $28: 10-17$ & Matthew 1:18-21 & Joseph, 12:4-6 \\
\hline 12. & $\begin{array}{l}\text { Encountering } \\
\text { God } 1\end{array}$ & Exodus $3: 1-8$ & Acts 9:1-9 & Та На 20:9-23 \\
\hline 13. & $\begin{array}{l}\text { Encountering } \\
\text { God } 2\end{array}$ & Genesis $3: 6-13$ & John 20:11-18 & Mary, 19:16-22 \\
\hline 14. & Fasting & Isaiah 58:4-7 & Matthew 4:1-4 & The Cow, 2:183-5 \\
\hline 15. & Food & Leviticus 11:41-47 & $\begin{array}{c}1 \text { Corinthians } \\
8: 8-13\end{array}$ & The Bee 16:65-69 \\
\hline 16. & $\begin{array}{c}\text { Gates and Doors } \\
1 \\
\end{array}$ & Genesis $28: 10-22$ & Acts 5:17-25 & Sura 39:68-75 \\
\hline 17. & $\begin{array}{c}\text { Gates and Doors } \\
2 \\
\end{array}$ & Exodus 12:21-32 & John 10:1-10 & Joseph 12:21-29 \\
\hline 18. & Joseph & Genesis $41: 38-44$ & Acts $7: 9-15$ & Joseph 12:19-22 \\
\hline 19. & Leadership & Numbers 27:15-20 & Mark 9:33-37 & $\begin{array}{c}\text { The family of Imran, } \\
3: 156-160\end{array}$ \\
\hline
\end{tabular}

Inter-faith dialogue is always a complex and challenging endeavor. Specifically, in Indonesia, discussing religious texts can be a sensitive exercise [10]. Furthermore, in many private universities, while Religion is a required course, only one is offered. Typically in a Christian university in Indonesia, a course on Religion means Christian Religion. On the other hand, students from the backgrounds of non-Christian religions are not unusual. Their presence in the class room can be a challenge, and it may also incite the feeling of alienation and displacement. The same case can be found in universities that are nonChristian faith-based institutions.

In this context, conducting an inter-faith approach is proposed as one of creative ways to improve the learning-process for the greatest benefit of all students. To explore this possibility, several inter-faith dialogues were conducted in the classroom through the use of CSR texts. There are several reasons why the texts is chosen. First, the texts consist of comparison according to similarity of theme that is practical for class-setting. There are 
many themes that can be used according to different interest and context of the participants. Second, the texts contain English translation and original language that helps to open conversation and generates textual exploration. Participants from various levels of religious comprehension can interact in dialogue while engaging with good quality original sources. Third, the texts are short enough to discuss and compare in a two-credit hour class. The key strategy of the approach is to focus on a short portion of the text. While knowledge of the original language and other texts that discuss similar theme can be used, the discussion has a very sharp focus on the theme based on the given texts. This places all student on the same level playing field. Fourth, the texts are published by a reputable university (Cambridge University) that lends a high academic credential for its use in a university setting. Students who may find the approach provocative can be persuaded to consider the expertise of the institution in providing reliable texts. And finally, the texts discusses basic and practical themes in religion that are less controversial and can generate a more peaceful engagement. In contrast to themes that may offend its adherents, the select topics while still intriguing, avoid controversial issues and help to ease the feeling of participants across different faiths in the interaction.

On the other hand, there are several challenges in using them in Indonesia. First, the texts are created in European context, as such, it only has texts from three out of six public religions in Indonesia, namely Islam, Catholic and Protestant. The other three religions, namely Hindu, Buddha and Kong $\mathrm{Hu} \mathrm{Chu}$, are not represented by the texts. Second, there is always certain risk of misunderstanding from students who are surprised by the novelty of the approach. Particularly, in our experiences, because the class is conducted in a Christian University, some Christian students are expecting an exploration of Christian faith, and Muslim students may find the use of Quran requires certain expertise in its interpretation. Third, most of the students have some kind of bias toward other religions and it can be a psychological barrier to get them into an honest and open discussion. And finally, most of the students have never been engaged in an inter-faith dialogue. Nevertheless, despite such challenges, with the consent of all students, all participants welcomed the approach and intrigued by the opportunity to engage each other.

\section{Qualitative explorations}

The experimental dialogues were conducted in three parallel classes of Ukrida's Faculty of Medicine. The population is 249 students which consist of 99 Christians, 45 Catholics, 74 Muslims, 23 Buddhists and eight Hindus. The percentage of the participant's religious background to population of students can be seen in Table 2 . The numbers shows that more than $40 \%$ non-Christians were taking the class. The population was divided into three classes, and each class has 80 to 84 students. They underwent five inter-faith dialogues of two-credit hour.

Table 2. Number and percentage of the participants according to religion

\begin{tabular}{|c|c|c|}
\hline Population & $\mathbf{2 4 9}$ & $\mathbf{1 0 0} \%$ \\
\hline Christian & 99 & $39.75 \%$ \\
\hline Catholic & 45 & $18.07 \%$ \\
\hline Muslim & 74 & $29.71 \%$ \\
\hline Buddhist & 23 & $9.23 \%$ \\
\hline Hindus & 8 & $3.21 \%$ \\
\hline
\end{tabular}

The class began with an opening prayer according to different religious traditions. Before entering the inter-faith sessions, there were several lectures on the meaning of 
religion, its general characteristics and similarities and differences among world religions. The inter-faith dialogues were consisted of discussions and open interactions. Each session begins with a reading of a text both in English and in its original language, followed by discussion of its meaning, in which the interpretation of the adherents of a religious text was treated with a special privilege. Because the class was quite large, the discussion was focused on the similarities and differences between texts from across faith backgrounds. In general, students responded positively to this pedagogical decision. Following the experiment, a qualitative interview was conducted to explore the experiences of the students. Since the dialogues is a new phenomenon, six qualitative interviews were conducted to find what is going on in the mind of the students. The participants were consist of representative from different religious backgrounds, namely Christian (1), Indonesian Muslim (1), Malaysian Muslim (1), Buddhist (1), Hindus (1), and Catholic (1).

The interviews were conducted in Bahasa. Each participants were asked a set of open questions to explore their personal experiences, perception and changed-actions following the class. The interviews show that there are interesting dynamics in four areas of student experiences, namely in knowledge, attitude, perception and sense of belonging. The followings are verbatim translations from the excerpt of their personal experiences and opinions, introduced and followed by our analyses.

\section{New positive experiences in knowledge and attitude}

The interviews shows that students who participate in the dialogues have a new positive experience in knowing better other religions. They also show a new positive experience in recognizing other's attitude toward their religious beliefs. The followings are some of the narratives on their experiences.

\subsection{Participant 1}

The first participant is a female Buddhist student who attended a Catholic high school before coming to Ukrida. She remembered reading Psalms and studying Catholic teachings but she never read Quran and listened to its chant. When parts of Quran and Bible were read and discussed in the class, she was thrilled and excited to find similarities and differences between the texts, and between the texts and her perception of the religions. The experience of praying together with adherents of various faiths was a very enlightening one. The following is an excerpt from her interview.

"I found CSR texts provide a good content of religion from Christian, Catholic and Islam. When my friend chanted Quran in the classroom it was my first experience.

In the beginning I found it a strange experience, listening to something I do not understand. But later on it change my point of view because after the discussion there are many similarities with the teaching of my religion.

There is improvement in my tolerance after the class since I consider myself quite tolerant. I have no problem if other students from different faith read my Holy Scripture but I think adherents of each religion should be given the privilege to explain the meaning of their own Scripture.

I believe this method can be used in other university including non-Christian universities such as public university."

One hypothesis that comes from this interview is that the feeling of distant and alienation are slowly eased when a student continuously involved in an inter-faith dialogue. The experience also enhanced previous tolerance that one had toward other religions. 
Finally while reading others' Scripture is accepted, there is an attitude of respecting others that was expressed in honoring the interpretation of the adherents of a particular text.

\subsection{Participant 2}

The second participant is a Muslim male student from Malaysia. Before coming to Indonesia, he was introduced to other religions from his formal education. But he never read Holy Scriptures from other faiths or involved in an inter-faith dialogue. Although his perceptions on other religions was not changed but his tolerance grew following the interfaith dialogue in the class. He explained that Malaysia have a very strict rule about respecting other faith and leave the matter as a private business.

"I share with my friends about this class and we found this approach more helpful compared to other classes which only learn Christian religion.

I never previously read others' Holy Scriptures. Although I still have the same perception about them, but I grow in my tolerance of their teachings because of the class.

Because we use CSR texts I have better knowledge about other religions. I think this is a good way to learn religions.

I found religious founders from other faiths are also respectable and champions of truth in a different ways.

I believe the class is a better way to approach the subject instead of studying a single religion.

After the class, sometime students asked me about Islam prayer and I also asked them about Christmas. I think talking about religions is not a problem here, although there are differences among us."

The interview shows that students discussed about their experiences outside the class, where he and his peers found that the approach is more beneficial than learning only Christian faith. He witnesses that the approach generates positive conversations amongst students and preferable compared to learning tenets of Christian religion, including the proposition that reading other's Scriptures is a healthy experience that helps to cultivate an attitude of tolerance and harmony across different religions. Specially, the CSR text is perceived as providing a good and reliable information of other religions. In his experience, the text helps students to interact with religious founders of other faith, and to appreciate their respective religious ideas.

\subsection{Participant 3}

The third participant is a Hindus female student who previously never read Holy Scripture of other religions but believes that every religion, in different ways, teaches the same truths. She had a previous experience in an inter-faith dialogue. She was excited when Quran was read in Arabic and the Bible was read in Hebrew and Greek during the class.

"I was excited to read Quran and the Bible in their original languages; I found many similarities with my Holy Scripture in Sanskrit.

During and after the class my appreciations of other religions was improving, I have more respect for other believers.

I have more tolerance and I hope in the future the lecture can consider our Holy Scripture to be read in Sanskrit

I am OK if students from different faiths interpret my Holy Scripture in fact I am curious to learn what they would say about its meaning 
One thing that I value from the class is the opportunity to share our faith with other students. I really enjoy the opportunity. I believe this approach should be applied in other universities."

The interview shows that although the class did not interact specifically with her religious texts, the student still had a positive experience. She experienced that reading the text in its original language is intriguing. The strangeness of the languages does not incite negative feeling, but spurs a feeling of adventure and in-depth exploration because the student can read the meaning of the supposedly ancient text in the translation. The interview suggests that reading one's own Scripture in the original language in the class incites a sense of belonging within the community. The reading of the text develops the attitudes of tolerance and also motivates student to share her own faith that teaches similar ideas with the discussed texts.

\section{New experiences that impact perception and sense of belonging}

The following interviews show that students have positive experiences in knowing other's perception of one's religious beliefs. The dialogues became an occasion to engage each other in a constructive way. Furthermore, the dialogue also contribute to one's sense of belonging in the class. Understanding each other helped the student to have mutual respect toward others' religious practices.

\subsection{Participant 4}

The fourth participant is a female Christian student who previously had read Quran out of curiosity in conversation with a maid in her house. At the beginning, she was surprised by the method of studying religion. She always curious to learn about other religions and found the class a good opportunity to learn other faiths. She had a basic tolerant toward other religions and interested to engage people of other faiths.

"I find the approach very fascinating. Compared to my high school experience CSR method is much more interesting.

I found so many similarities between religions and I wonder whether there is much more to be found. The class really intrigued me to find if it is so.

When I discussed with my friends, our conversation was not too deep. But in the class we explored deeper, and everything become very fascinating.

I realized that radicalism and intolerance are quiet common in Indonesia, and sometime I am disappointed. But after the class I have less negative perception about others, because I see that the religion itself is a good thing

This method is very different from high school which is I find boring. But discussing the texts I found so many interesting things.

In engaging other believers I learn to be more tolerant. We can read the texts itself, free to have different interpretations and give our arguments. But in the end we try to come to conclusion that acceptable to everybody."

The interview suggests that the approach helps the student to clarify her understanding of other religions. When a discussion presents a reliable understanding of a particular religion, and not just a biased construct, it spurs excitement and fascination. What struck her more was the similarities between religions are much more that she previously perceived. The hypothesis that can be suggested from the interview is that students in general have interest to know about other religions. Since a good inter-faith dialogue is difficult to find, the approach taken in the class is a rare opportunity for learning and 
understanding. She also likes the fact that different interpretations are allowed in the class, but at the same time there is an expectation to find ways that unites different readers to come to a conclusion that is acceptable to all participants.

\subsection{Participant 5}

The fifth participant is a female Muslim student who has an initial reservation studying in a Christian university. But her confidence toward a pluralistic community grows significantly after the class. She developed a new sense of belonging compared to her previous perception on the difficulty making friend in a Christian university. She found the approach of the class made the course belonging to every students with different backgrounds and suggested that the pedagogical strategy should be applied for next batch.

"I never read other Holy Scriptures previously. Sometimes when I have dialogue with people of different faiths, we offended each other. So, it was mostly negative.

In the class we begin and end with prayer. I was surprised when people from non-Christian background were invited to lead the prayer. I immediately volunteered myself.

CSR help me to be more tolerant and friendly to people of different faiths.

I have no reservation if people from other faiths read and interpret Quran in the class. If there is misunderstanding, the Muslim students can help them to understand.

The class helped me to have a sense of belonging in Ukrida. So, it is not only for Christian but also for Muslim.

I greatly appreciate when my Christian friends reminded me to do my daily prayers (Sholat), I feel when people from other faiths, remind me about that, it really embarrasses me, but also motivates me. You see, she is not a Muslim but she reminds me."

The interview suggests that a class-setting inter-faith dialogue was a more positive experience compared to her previous inter-religious conversation. In the experience of the student, leading a class in prayer according to her faith, changed her perception and inspired a sense of belonging. The interview also suggests that the method helped her to be more tolerant toward people of other faiths. The interview shows her growing positive experience, and how the class helped her in reducing anxiety about studying in a Christian university. This is exemplified in the acted-out responses of religious interaction where she experienced motivating social impulse coming from friends of different religious backgrounds to exercise her religious obligation.

\subsection{Participant 6}

The sixth participant is a Catholic student who noticed the impact of the class for relationship between students in his batch. According to his observation, the class, which was conducted at the early year of study, helped to build a harmonious community of students. He previously had a pluralistic understanding of religious truth, but the class helped him to understand other faiths better and deeper.

"Previously I had never ever read other Holy Scriptures. Sometimes I had debates with my friends about religion, and they tell me about their faith.

I found the class very interesting. Everybody can express their religion. My Muslim friends chanted a portion of Quran from CSR. And they also can use Quran to lead the class in prayer.

I believe conviction is about free will. Everybody has their own free will.

The class help us to be united. There is no division among us because we learn to be tolerant to each other. When some are fasting we respect them. When we celebrate Christmas my friends also greet us and respect the holy season. 
I found the inter-faith dialogue very positive. I found no negative comments from my friends. And I did not find any negative excess when the lecturer used this approach.

Personally, the method help me to be closer to God. I realize I am nothing to God. I see there is no reasons to be fanatics. The truth of God, I can see myself, is to be found in many religions."

The last interview suggests a general response of the class to the method, particularly because the respondent was one of the class reps, and observed the positive attitudes of his classmates to the method. The interview suggests that when a Muslim student read Quran in a Christian institution was a very positive occasion. It helps creating acceptance and avoid alienation. In his experience, the approach contributed to the harmony of the class and helped them to avoid division. The unity found its expression in religious harmony that respects each other in religious duties and celebrations. In his interaction with his class mates no student gave negative comments, or if there was, it was not expressed in a way that he could perceive. Finally, the interview suggests that the inter-faith dialogue also helped the participant in his faith to God, and it is expressed in his conviction that the truth can be found in each religion.

\section{Conclusions: Some pedagogical recommendations}

Based on these qualitative interviews, conclude that using CSR texts in a class-setting was a positive experience among respondents and help them to grow in tolerance toward other religious faiths. Because the study of religion has been obligated to all students since primary to high school in Indonesia, a new experience is welcomed as a positive novelty and excites students in reading and listening various religious views. In this regard, this pedagogical approach has a potential to be used in a more diverse community such as a dialogue between youths in local mosque and church. Another possible application is in the class on religion in the high school. This can be done as part of Service-Learning on Religion Class which is a required subject in university in Indonesia. By conducting the dialogue the student may experience a deeper understanding of differences and similarities among religions.

The challenge to do so is the feeling of inadequacy among students to conduct such dialogue. Further experiments are needed before the approach can be implemented in a Service-Learning class. The recommendation that the composition of the class consist of inter-faith dialogue in the class (at least $50 \%$ of the class-meetings) that the students then replicates in a local community. The dialogue as such is not a first experience but rather a reiteration of their own experience in a new context. To achieve this, some experiments among youths in local religious institutions that involve their respective clergy can provide important lessons for Service-Learning implementation. Nevertheless, from what had been done in our classes, the following principles can be suggested as pedagogical principles in conducting inter-faith dialogue using CSR text: i) the importance of the participant's consent, ii) the acknowledgement of special authority, and iii) the provision of space for individual testimony.

\section{References}

1. K. Hidayat. Radikalisme Menyusup ke SMU. [Infiltrating Radicalism to High School] In: Terorisme Di Indonesia : Dalam Tinjauan Psikologi. [Terrorism in Indonesia: In Psychological Review]. S.W. Sarwono (Ed). Jakarta: LaKIP (2012). p. 119-123. [in Bahasa Indonesia]. 
https://books.google.co.id/books/about/Terorisme_di_Indonesia.html?id=-

BnYECkUc2oC\&redir_esc $=\mathrm{y}$

2. Wahid Foundation. Laporan Tahunan Kemerdekaan Beragama dan Berkeyakinan 2016. [Annual Report on Freedom of Religion and Belief in 2016]. [Online] from http://wahidfoundation.org/index.php/publication/detail/Laporan-Tahunan-WahidFoundation-tahun-2016 (2016). [in Bahasa Indonesia]. [Accessed on April 21 ${ }^{\text {st }} 2017$ ].

3. Wahid Foundation, National Survey Report, A Measure of the Extent of SocioReligious Intolerance and Radicalism within Muslim Society in Indonesia, 2016 [Online] from http://wahidfoundation.org/source/download/National_Survey_Wahid Foundaiton.pdf (2016). [Accessed on April 26 ${ }^{\text {th }}$ 2017].

4. D.N. Rosidin. Muslim Fundamentalism in Education Institutions: A Case Study of Rohani Islam in High Schools in Cirebon. In: Islam in Indonesia : contrasting images and interpretations. J. Burhanudin, K. Dijk (Eds). Amsterdam: Amsterdam University Press (2013). p. 215-226. http://en.aup.nl/books/9789089644237-islam-inindonesia.html

5. D. Ford, C.C. Pecknold. The Promise of Scriptural Reasoning. Oxford: Blackwell (2006). p. 1-22. http://as.wiley.com/WileyCDA/WileyTitle/productCd1405146303.html

6. D. Ford. Christian Wisdom : Desiring God and Learning in Love. Cambridge: Cambridge University Press (2008). p. 273-303.

http://www.cambridge.org/us/academic/subjects/religion/theology/christian-wisdomdesiring-god-and-learninglove? format $=$ HB\&isbn $=9780521875455 \#$ Bx1b6DYIRIozIEGY .97

7. The Cambridge Inter-Faith Program. Scriptural Reasoning Online 2017 [Online] from https://www.interfaith.cam.ac.uk/sr/sronline (2017). [Accessed on April $26^{\text {th }} 2017$ ].

8. Rose Castle Foundation. Reflecting together on Sacred Texts 2017 [Online] from http://www.scripturalreasoning.org/scriptural-reasoning-now.html (2017). [Accessed on April 26 $\left.6^{\text {th }} 2017\right]$.

9. Rose Castle Foundation, Scriptural Reasoning Text Packs 2017 [Online] from http://www.scripturalreasoning.org/text-packs.html (2017). [Accessed on April 27 $7^{\text {th }}$ 2017].

10. J. Menchik. Islam and Democracy in Indonesia: Tolerance without Liberalism. Cambridge: Cambridge University Press (2016). p. 19-24.

https://www.amazon.co.uk/Islam-Democracy-Indonesia-ToleranceLiberalism/dp/1107119146

11. H. Gadamer. Truth and Method. New York: Continuum (2004). p. 277-281. https://www.amazon.co.uk/Method-Continuum-Impacts-Hans-GeorgGadamer/dp/082647697X 